\title{
Preference Erosion and Multilateral Trade Liberalization
}

\author{
Joseph Francois, Bernard Hoekman, and Miriam Manchin
}

\begin{abstract}
Because of concern that tariff reductions in Organisation for Economic Co-operation and Development (OECD) countries will translate into worsening export performance for the least developed countries, the erosion of trade preferences may become a stumbling block for multilateral trade liberalization. An econometric analysis of actual preference use shows that preferences are underused because of administrative burdens-estimated to be equivalent to an average of 4 percent of the value of goods traded. To quantify the maximum scope for preference erosion, the compliance cost estimates are used in a model-based assessment of the impact of full elimination of OECD tariffs. Taking into account administrative costs eliminates erosion costs in the aggregate and greatly reduces the losses for countries most affected by preference erosion.
\end{abstract}

Nonreciprocal trade preferences have long been granted by Organisation for Economic Co-operation and Development (OECD) countries to various developing countries. In the early history of the General Agreement on Tariffs and Trade, the pattern of these preferences reflected old colonial trade ties. In 1968, the United Nations Conference on Trade and Development (UNCTAD) recommended creation of a Generalized System of Preferences under which high-income countries would grant trade preferences to all developing countries on a nonreciprocal basis. The jury remains out on whether trade preferences have actually made a substantive difference in the welfare of recipient countries. The developing countries that were granted the fewest preferences at the inception of the program in the 1960s, those in East Asia, have subsequently grown

Joseph Francois is professor of Economics in the Department of Economics at Erasmus University Rotterdam, fellow at the Tinbergen Institute, and research fellow at the Centre for Economic Policy Research; his email address is francois@few.eur.nl. Bernard Hoekman is research manager in the Development Research Group at the World Bank and research fellow at the Centre for Economic Policy Research; his email address is bhoekman@worldbank.org. Miriam Manchin is a research fellow at Centro Studi Luca d'Agliano; her email address is miriam.manchin@guest.unimi.it. The authors are indebted to Nuno Limão, Marcelo Olarreaga, Sheila Page, and Susan Prowse; to the journal editor; and to three anonymous referees for constructive comments and suggestions. They also gratefully acknowledge support from the U.K. Department for International Development project "Global Trade Architecture and Development" and from the EU Research Training Network "Trade, Industrialization, and Development." 
the fastest. Those granted the deepest preferences, including the least developed countries in Sub-Saharan Africa, have not managed to increase their per capita incomes or diversify their exports significantly in the last 40 years. To a large extent, outcomes in both regions are due more to domestic policies and institutions than to trade policies in OECD countries. Most analysts would agree that the major constraints on export diversification and expansion in Africa are the investment climate and supply capacity.

Whatever the intended and actual impacts of trade preferences, they are a central issue in the ongoing efforts to negotiate further multilateral trade liberalization. Middle-income countries are increasingly concerned about the discrimination they confront in OECD markets as a result of free trade agreements and the better access granted in these markets to poorer or "more preferred" developing countries on a nonreciprocal basis. Conversely, preferences are used as an argument by the least developed countries and African countries against a general liberalization of trade and removal of trade-distorting policies in agriculture by OECD members, because of fears about the potential negative effects of an erosion of preferential access. ${ }^{1}$

This article explores the economic relevance of trade preferences in the context of World Trade Organization (wTO)-based multilateral liberalization. This involves both an econometric assessment of the extent to which preference schemes are actually used and a numerical assessment of the dollar value of potential preference erosion associated with further wTO-based, nondiscriminatory tariff reductions. The numerical analysis assumes that the principle of nonreciprocity continues to prevail-developing countries are assumed to benefit from preferential access to OECD markets without reducing their own protection. ${ }^{2}$ While many analysts have argued that nonreciprocity imposes costs on developing countries because it reduces the incentives of partners to liberalize while maintaining their own trade barriers, from the perspective of quantifying the magnitude of potential preference erosion, nonreciprocity is an appropriate constraint to impose. What matters is the loss of benefits stemming from the removal of an explicit development-motivated policy that has been put in place by OECD countries.

\section{Administrative Burden and the Use of Preferences}

A key question when evaluating the value of trade preferences to beneficiaries is the cost of obtaining the preferences. Traders requesting preferences must comply with administrative and technical requirements. The most important requirements are related to compliance with rules of origin (see Cadot and others

1. They are also concerned about the potential negative terms of trade effects of multilateral liberalization insofar as this raises the price of their imports, especially of goods that currently benefit from subsidies and protection in OECD markets, by more than the price or quantity of their exports.

2. See Anderson, Martin, and van der Mensbrugghe (2006) for an analysis of the relative contribution of liberalization by developing countries to global welfare. 
forthcoming), which define the conditions that a product must satisfy to be considered as originating from the exporting country that has been granted preferential access. Rules of origin are intended to prevent trade deflectionrouting exports from nonbeneficiaries through a participating country to avoid customs duties (Brenton and Manchin 2003). When products are produced in a single stage, origin is relatively easy to establish. For all other cases, the rules of origin define the criteria that determine whether the product has been sufficiently processed in the exporting country to qualify for preferential access. Rules of origin have become more important as technological progress and globalization increasingly fragment production processes into stages that are undertaken in different locations.

In an early study, Herin (1986) argued that the costs of documentation and administration of origin rules applied by the European Economic Community imposed costs on exporters in European Free Trade Association countries equivalent to some 3 percent of the value of the goods traded. More recent work on the North American Free Trade Agreement (NAFTA) by Carrère and de Melo (2004) finds that total compliance costs for Mexican exporters to the United States averaged 6.2 percent in 2001. Using double-censored Tobit estimation techniques, they obtain a compliance cost estimate of 3.9 percent for products where the use rate is below 100 percent. $^{3}$ For developing countries, these costs are expected to be even higher because of information disadvantages and institutional weaknesses.

\section{The Estimating Framework}

A threshold technique is used to find the minimum preference margin (the difference between the preferential and nonpreferential tariff) below which traders have little or greatly reduced incentive to ask for preferences because the costs of obtaining them exceed the benefits. Data availability constrains the analysis to the preferential trade relations between African, Caribbean, and Pacific (ACP) countries and the European Union (EU) under the Cotonou agreement. Nevertheless, the assessment should provide a more general proxy for the costs traders from developing countries have to bear for requesting or obtaining preferential access. ${ }^{4}$

Because factors other than preferential margins may influence decisions to ask for preferences, Hansen's (2000) technique is used to endogenously determine a threshold in the relationship of interest while controlling for other factors. The threshold estimation technique is ideal when data must be split into subsamples to examine the relationship of interest. This approach allows the estimated

3. See also Anson and others (2005), who estimate that average compliance costs in NAFTA are about 6 percent, offsetting the preferential tariff differential of about 4 percent. Administrative costs chewed up about half the value of preferential access for Mexican firms.

4. Section III does take into account that for a subset of least developed countries, the U.S. African Growth and Opportunity Act (AGOA) has substantially reduced the costs of rules of origin. 
regression coefficients to differ depending on the value of a particular parameter. The threshold estimation model can be written as follows:

$$
y_{i}=\beta^{\prime} x_{i}+\delta_{n}^{\prime} x_{i}(\gamma)+e_{i}
$$

In equation (1), $\gamma$ is the threshold parameter that splits the sample into two subsamples-here the threshold value under which traders have no incentive to request preferences- $\beta$ and $\delta$ are sets of coefficients applying to explanatory variables $x$ and $x_{i}(\gamma)=x_{i} d_{i}(\gamma)$. The term $d_{i}(\gamma)$ is a dummy variable identifying the threshold value for the splitting parameter, which is the difference between preferential and most favored nation tariffs. The first step is to identify the threshold value of $\gamma$ and the other coefficients. This is done with an algorithm from Hansen (2000) that searches through the values of $\gamma$ until the splitting value is found [this is the value of $\gamma$ that minimizes the concentrated sum of squared errors based on an ordinary least square (OLS) regression].

The decision to use preferences depends on the net benefit from requesting them. At the margin, this requires balancing the costs of obtaining preferences against the resulting benefits. This is influenced by source market characteristics, the characteristics of the market being supplied, and transportation and other transaction costs. Thus, use rates are expected to map to the same variables that determine trade itself. Therefore, in identifying $\gamma$, standard gravity model variables are used. As a proxy for the trading countries' market size, the gross domestic product (GDP) ( $\mathrm{GDP}_{i}$ is the level of income in country $i$ ) of both partner countries is included in the regression. ${ }^{5}$ GDP data are taken from the World Bank's (2005) World Development Indicators database. The level of development of the country or the quality of its economic environment can also influence the net revenue from using the preferences. Therefore, an indicator of economic freedom (Freedomindex) was included in the regression. The index was obtained from Freedom House's Freedom in the World database. ${ }^{6}$ The lower a country's index, the more economic freedom the country has.

The more distant trading partners are from each other, the higher transport costs will be. Distance $\left(D_{i j}\right)$ is therefore a proxy for transport costs. The data originate from the Paris-based Centre d'Etudes Prospectives et d'Informations Internationales (CEPII) distance database. ${ }^{7}$

The transaction costs for using the preferences might be lower between countries with historical links. To proxy for these links, two zero-one type dummy variables were included in the regression. FrenchExcolony $y_{i j}$ and NonFrenchExcolony $i j$ take a value of 1 if the exporting country $(i)$ was a colony of France or other partner country $(j)$. Colonial links often reflect not only historical ties but also that the traders speak the same language. A separate dummy

5. As a robustness check, further specifications were estimated using population and income per capita as a proxy for the size of the economies. All yielded the same threshold value.

6. For details see http://www.freedomhouse.org/research/freeworld/2003/methodology.htm.

7. For details see http://www.cepii.fr/anglaisgraph/bdd/distances.htm. 
variable is included for non-French former colonies and for French former colonies because there might be differences in the intensities of the trade links for French former colonies. ${ }^{8}$

In many aspects, such as size of the economy or level of development, South Africa differs from most of the other ACP countries in the sample. To avoid having specificities of South Africa drive the results, a dummy variable taking a value of 1 if the exporting country is South Africa is included in the regressions. SECDUM $_{i j k}$ is a set of $k$ dummy variables for agriculture, textiles, clothing, footwear, machinery, and mineral products. ${ }^{9}$

Finally, net revenues that can be earned from using the preferences are assumed also to depend on the size of preferences available as measured by the difference between most favored nation and preferential tariffs for each product $k$ (Dutydifference ${ }_{k}$ ). This is the variable for which a threshold value of $\gamma$ is identified.

To identify the threshold value in the preferential margin, the following equation is estimated using oLs:

$$
\begin{aligned}
\ln _{\mathrm{UTIL}_{i j k}=} & \alpha+\beta_{1} \ln \mathrm{GDP}_{i}+\beta_{2} \ln \mathrm{GDP}_{j}+\beta_{3} \ln D_{i j} \\
& +\beta_{4} \text { FrenchExcolony }_{j}+\beta_{5} \text { NonFrenchExcolony }_{j} \\
& +\beta_{6} \text { Freedomindex }_{j}+\beta_{7} \text { SouthAfrica } \\
& +\beta_{8} \text { Dutydifference }_{i j k}+\sum_{i j k} \beta_{i j k} \mathrm{SECDUM}_{i j k}+e_{i j k} .
\end{aligned}
$$

In equation (2), $\mathrm{UTIL}_{i j k}$ is the use rate of Cotonou preferences for product $k$, or the percentage of country $i$ 's imports of product $k$ from country $j$ for which preferential access was requested. As the use rate ranges from 0 to 1 , a logistic transformation of the observed use rate is applied, setting zero rates to 0.001 and full use rates to 0.999. The data are import flows for 2001 from Eurostat at the eight-digit level of product disaggregation.

\section{Estimation Results}

The 95 percent confidence interval (CI) for the threshold estimates (cut-off value) places the threshold between the 48 th and 52 nd percentiles. This implies that the preferential tariff must be $4-4.5$ percentage points lower than the most favored nation tariff for traders to request preferences. This CI is plausibly tight: only 341 of 23,685 observations fall within the 48th and 52nd percentiles. With 1,000 bootstrap replications, the p-value for the threshold model is significant at the

8. Only four countries in the sample were not colonies.

9. Of the 23,685 observations, 9,015 are not covered by any sectoral dummy variable. These observations belong to sectors such as metals, vehicles, optics, chemicals, plastics, stones, and glass. 
2.5 percent level. In terms of use rates, 70 percent of observations where preferences were requested were above the threshold and 30 percent were below. The average use rate is 16 percent when the duty reduction is less than 4 percent and 43 percent when it is more than 4 percent. That some traders request preferences when benefits are very limited could reflect lack of information about the preference scheme or the fact that costs are only measurable ex post. ${ }^{10}$

To test the robustness of the results, the threshold regressions were also run with country-specific fixed effects instead of the country-specific variables. The same threshold values were obtained for all the specifications: the preferential tariff must be lower than the most favored nation tariff by $4-4.5$ percentage points. ${ }^{11}$

Table 1 reports ols estimates using the logistic transformation for the threshold model based on the threshold value of a 4 percent duty difference for country-specific explanatory variables and country-specific fixed effects. The variable belowthreshold measures duty reduction when the difference between the most favored nation and preferential duty is smaller than the threshold, whereas the variable abovethreshold measures duty reduction when the difference is higher than the threshold. The results confirm that the threshold value was correctly identified. The coefficient of the variable belowthreshold is negative. When the duty reduction is above the 4 percent threshold, the probability of using the preference scheme rises. Thus, there is a different relationship between tariff reduction above the threshold and use of preferences and between tariff reduction below the threshold and the use of preferences.

While not reported because of space constraints, the threshold was also estimated separately for a split sample that distinguishes agricultural from nonagricultural products. Both estimates of $\gamma$ remain significant at the 5 percent level. The manufacturing threshold is identical to the full-sample threshold, whereas the agricultural threshold is somewhat higher, at 15 percent. Higher rates for agriculture appear counterintuitive in that the consensus in the literature is that it is easier to prove origin for such products (Stevens and Kennan 2004). ${ }^{12}$ The higher threshold for agriculture may reflect, in addition to rules of origin, compliance costs related to technical and sanitary requirements and the procedural requirements associated with the administration of quota-guaranteed access to protected markets. These procedural requirements are important for

10. Several observations in the dataset indicated that some traders requested preferences even when preferences were not available, which also confirms that thorough understanding of the preference scheme might be lacking.

11. The p-value for the threshold model using country-specific fixed effects was not significant.

12. Candau, Fontagné, and Jean (2004) find that underuse of preferences is highest in textiles and garments (for EU imports under both the Generalized System of Preferences and Everything but Arms programs). In the Everything but Arms program, exporters in principle benefit from 100 percent duty-free access but are found to pay up to 6.5 percent average tariffs. 
TAble 1. Endogenous Threshold Regressions: Logistic Transformation of Use Rate

\begin{tabular}{lcc}
\hline $\begin{array}{l}\text { Independent } \\
\text { Variables }\end{array}$ & $\begin{array}{c}\text { Model 1 Country-Specific } \\
\text { Explanatory Variables }\end{array}$ & $\begin{array}{c}\text { Model 2 Country-Specific } \\
\text { Fixed Effects }\end{array}$ \\
\hline Lngdp_i & $0.024(0.003)^{* * *}$ & \\
Lngdp_j & $0.028(0.002)^{* * *}$ & $-0.478(0.049)^{* * *}$ \\
Lndist & $-0.03(0.012)^{*}$ & \\
SouthAfrica & $-0.286(0.012)^{* * *}$ & $-0.056(0.016)^{* * * *}$ \\
Freedomindex & $-0.004(0.002)^{* * *}$ & $0.057(0.016)^{* * *}$ \\
FrenchExcolony & $0.038(0.013)^{* * *}$ & $0.263(0.007)^{* * *}$ \\
NonFrenchExcolony & $-0.018(0.007)^{* * *}$ & $0.205(0.012)^{* * *}$ \\
DUMagri & $0.262(0.008)^{* * *}$ & $0.109(0.017)^{* * *}$ \\
DUMtext & $0.229(0.013)^{* * *}$ & $-0.109(0.006)^{* * *}$ \\
DUMfoot & $0.116(0.019)^{* * *}$ & $0.346(0.014)^{* * *}$ \\
DUMmach & $-0.135(0.007)^{* * * *}$ & $0.06(-0.038)$ \\
DUMwood & $0.395(0.015)^{* * *}$ & $0.197(0.009)^{* * *}$ \\
DUMmineral & $0.022(-0.041)$ & $-1.046(0.211)^{* * * *}$ \\
DUMcloth & $0.235(0.009)^{* * * *}$ & $0.161(0.033)^{* * *}$ \\
Belowthreshold & $-1.403(0.226)^{* * *}$ & $3.74(1.05 \mathrm{E}+04)$ \\
Abovethreshold & $0.176(0.035)^{* * *}$ & 23,631 \\
Constant & $-0.332(0.127)^{* * *}$ & 0.36 \\
Number of observations & 23,631 & Included \\
$R$-squared & 0.27 & \\
Country-specific fixed effects & & \\
\hline
\end{tabular}

"Significant at the 5 percent level.

$*$ Significant at the 1 percent level.

Note: Estimates of threshold values are based on least squares estimation (see Hansen 2000). Numbers in parentheses are standard errors.

Source: Authors' analysis based on data described in the text.

commodities such as sugar and bananas in the Eu. ${ }^{13}$ It may also be that the lower unit values for agricultural products imply that the percentage equivalent for a given set of administrative requirements is higher.

To illustrate the implications of the estimated threshold level for trade preferences, consider Eu imports from least developed countries for 2001. Table 2 provides estimates of the rate of most favored nation protection that would be applied against least developed country exports to the EU (weighted by their exports), the share of imports by sector reported as actually entering the eu duty free, and the actual underlying trade flows. Note that for least developed countries, the most important exports (by value) are manufactured products, followed by mining products (generally duty free on a most favored nation basis). On average, many Eu tariffs in manufacturing are below the estimated threshold. Yet there are some peak rates that make preferences worthwhile in

13. De Gorter and Kliauga (2006) document the complexity of the administrative requirements associated with the implementation of quota regimes (tariff rate quotas). 


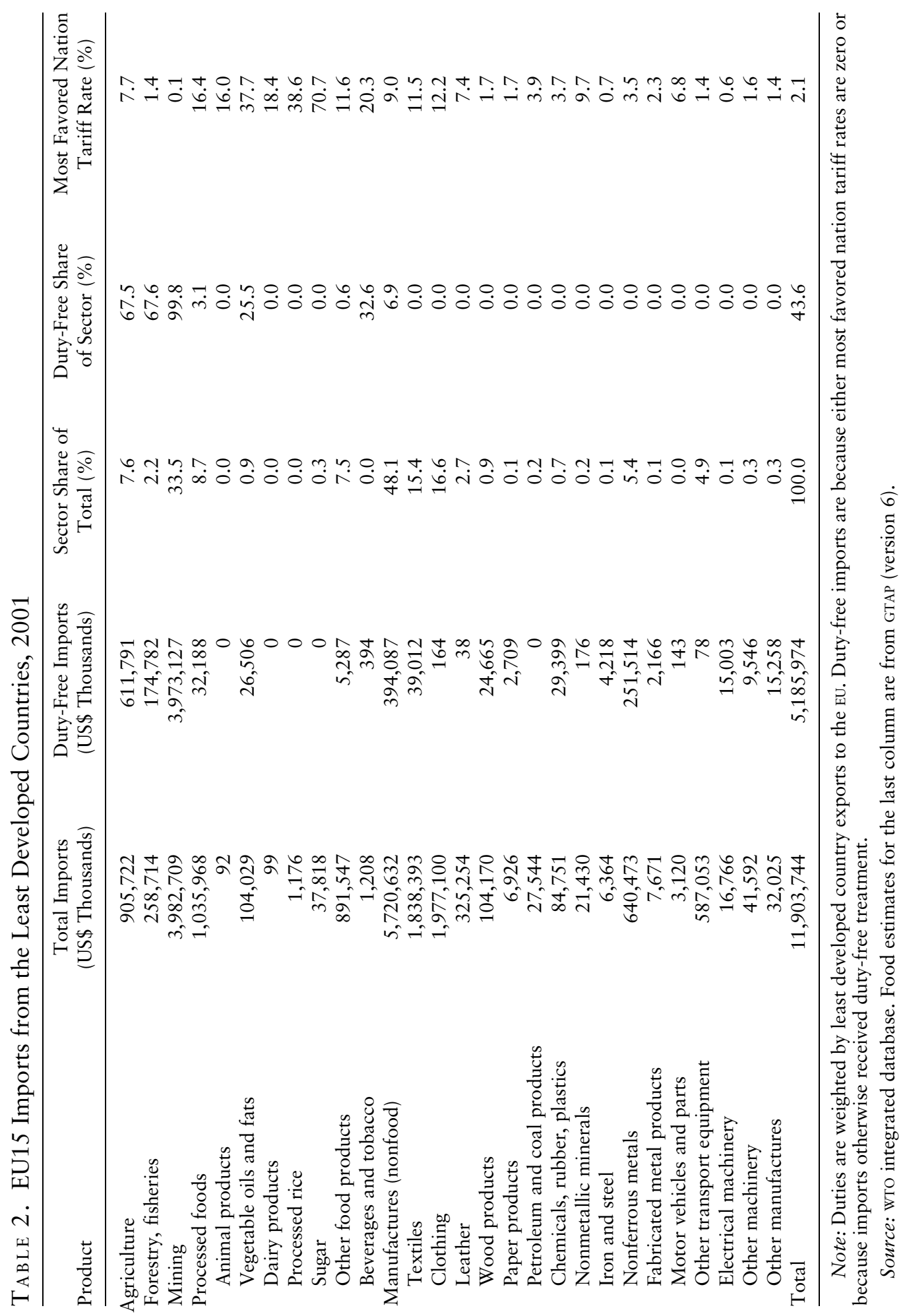


specific categories. Thus, the benefits of preference regimes hinge on the margin of preference at the tariff-line level. ${ }^{14}$

The highest use of preferences in 2001, as proxied by duty-free-eligible imports, was in agriculture and processed foods-products with rates of protection that are generally well above the identified thresholds. That agricultural protection is high and that preferences in this sector are often reflected in tariff quotas implies that high observed use rates are not inconsistent with the relatively high average split-sample threshold estimate: the implication is that the associated rents are high enough to cover the costs.

The results presented in this section indicate that traders require a certain minimum preference margin before they request preferences. If the difference between preferential and most favored nation tariff rates is less than that amount, there are no incentives for traders to request preferences, because the costs of obtaining the preferences are expected to be higher than the benefits of obtaining the preferences. This threshold for ACP countries in their preferential trade with the EU was between 4 and 4.5 percent overall, with higher costs for agriculture-based products. Although this figure pertains to a specific group of developing countries, it provides an approximation of the costs associated with preferential schemes for other countries as well, because the requirements are similar. The estimate is broadly consistent with others reported in the literature-see, for example, Cadot and others (2005, 2006, forthcoming).

\section{The Scope for Preference Erosion}

Next, a global general equilibrium model is used to provide a numerical assessment of the likely magnitude of preference erosion if OECD countries were to implement further multilateral tariff reductions. As mentioned previously, it is assumed that developing countries do not liberalize. In the model, preferences are included as part of the benchmark data, and the estimates of the administrative costs of preferences in the previous section are integrated in the assessment of the overall benefit of preferences.

\section{The Mechanics of Erosion}

To examine the basic mechanics of preferences and preference erosion, start with figure 1 , in which an archetype OECD country imports varieties of good $X$ from a least developed country supplier, $S_{\mathrm{LDC}}$, and from a non-least developed country supplier, $S_{\text {non-LDC. }}$ Trade preferences are represented by a reduction in the tariff applied to imports from the least developed country. The result is a new equilibrium in which there is an increase in exports by the least developed country supplier from $X_{\mathrm{LDC}, 0}$ to $X_{\mathrm{LDC}, 1}$. The benefit for the least developed country

14. Simple regression analysis of the data in table 2 confirms that the share of duty-free trade, and hence the implicit use of preferences, is indeed significantly and positively correlated with the peak tariff rates in the table. 
Figure 1. Impact of a Tariff Preference
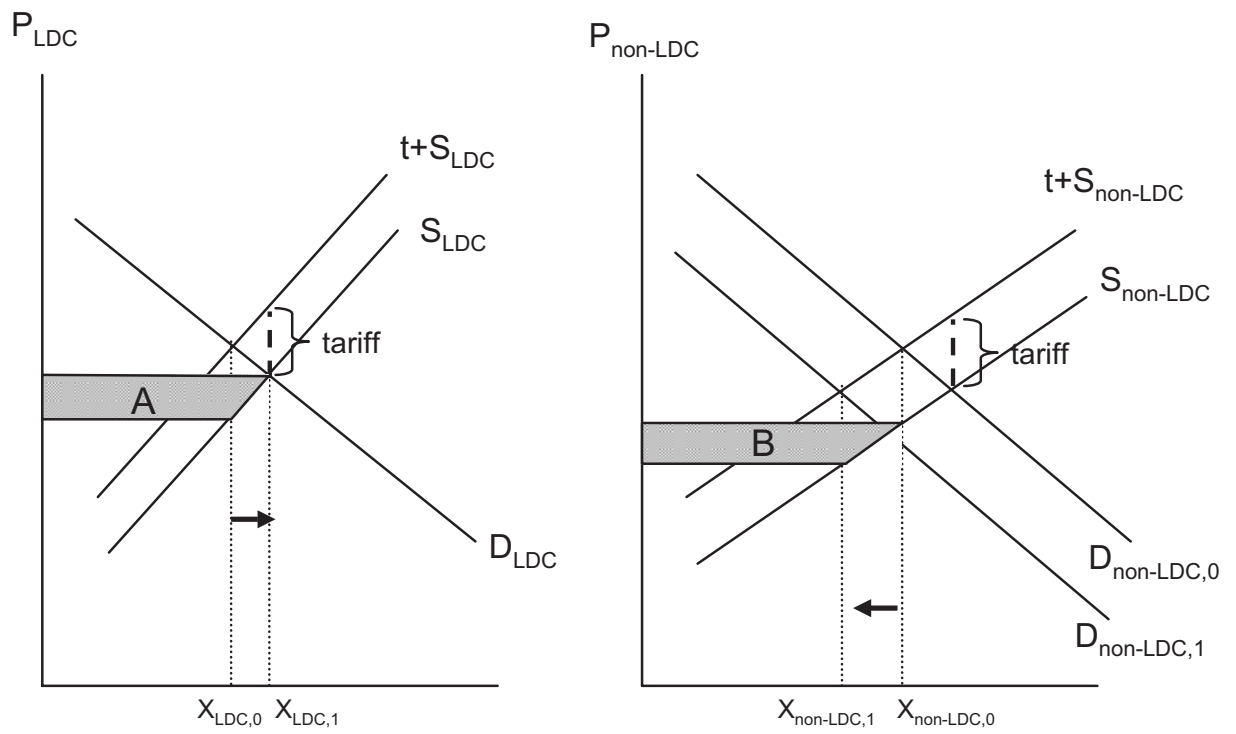

exporter is represented by area A. At the same time, there will be a shift in demand away from imports from the nonpreferential supplier, resulting in a cost represented by area $\mathrm{B}$, the loss in exporter surplus. The magnitude of these costs and benefits depends on underlying supply and demand responsiveness to price changes as well as on the degree of substitution between preferential and nonpreferential suppliers. The impact on the importer depends on a mix of effectsterms of trade, trade creation, and trade diversion.

On net, therefore, trade preferences involve a mix of benefits for preferential exporters, costs imposed on third-country exporters, and potential losses for the importer. ${ }^{15}$ Basically, trade preferences are a beggar-thy-neighbor type of foreign aid-robbing Peter to pay Paul. This is why there has been tension between the least developed countries, the "not-quite" least developed countries, and other developing countries in the context of WTO negotiations to liberalize trade.

Preference erosion involves the reduction or elimination of tariffs on the nonpreferential supplier, as shown in figure 2. Elimination of the tariff on the remaining third-country suppliers, given the duty-free access already granted to preferential suppliers, means that third-country exporters see their exports


in exporter surplus of area $\mathrm{E}$, which may be greater or less than the original loss of exporter surplus resulting from the preferences, area $\mathrm{B}$ in figure 1 . The

15. The impact can be represented in stages: an expansion of least developed country exports results in a subsequent fall in non-least developed country exports and price. Shown here is the final result of such an adjustment process. 
Figure 2. Impact of Liberalization by a Preference-Granting Country
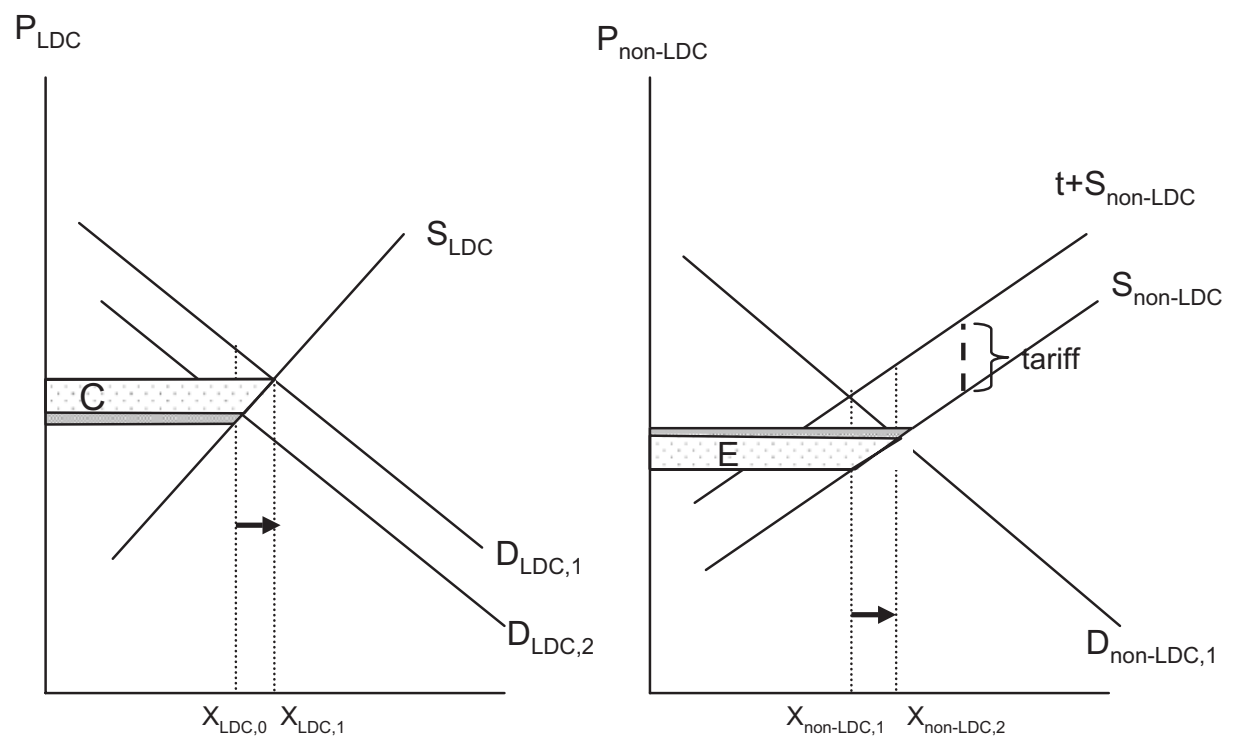

preferential supplier sees a drop in demand for its exports from $D_{\mathrm{LDC}, 1}$ to $D_{\text {LDC,2 }}$. This results in a partial loss of the benefits from the original preference scheme. This is represented by area $\mathrm{C}$, which is shown as being less than area $\mathrm{A}$ in figure 1 . The reason the loss is not complete is that preferences include the benefits relative to the original tariff-ridden equilibrium from a nondiscriminatory tariff reduction by the importer. Thus, preference erosion generally yields a partial, not a full, loss of the original benefits of the preference scheme. At the same time, third-countries recover some of the costs originally imposed by the preference scheme.

A few caveats are in order here. First, to the extent that either importers (Francois and Wooton 2005) or the transport and logistics sector (Francois and Wooton 2001) exercise market power, they can be expected to capture at least some of the benefits of tariff reductions rather than the exporters. There is evidence, based on the U.S. African Growth and Opportunity Act (AGOA) preference scheme that the pass-through of preference margins is indeed partial at best. Olarreaga and Özden (2005) find that exporters received an average of one-third of the tariff rent, with poorer and smaller countries tending to obtain lower shares-as low as 13 percent in Malawi. ${ }^{16}$ In addition, based on the analysis in the previous section, administrative costs related to these programs

16. See Özden and Sharma (2006) for an analysis of the Caribbean Basin Initiative program. Cadot and others (forthcoming) estimate the share of NAFTA tariff preferences that accrue to Mexican exporters of apparel at about 50 percent, once account is taken of the compliance costs associated with rules of origin. 
can be expected to chew up some of the benefits. Although not shown in the figure, this implies deadweight losses involving parts of areas A and C. In the case of market power, the result is a simple redistribution of the benefits of preferences (rents) to importers. With administrative costs, however, the share of the gains that is lost is not redistributed but is a deadweight loss. In both cases, the trade effects of preference programs will be less as well.

\section{A Numerical Assessment}

While considerable political weight has been attached to this issue, the debate has occurred largely in a vacuum, without real information on costs and benefits. The exceptions have focused almost exclusively on the effects of preference erosion on the exports of beneficiary countries. ${ }^{17}$ This section uses a global multiregion general equilibrium model of trade to provide a numerical assessment of the likely magnitudes of costs and benefits on nondiscriminatory trade liberalization by OECD members. The model includes 34 regions and countries and 24 sectors. ${ }^{18}$ The social accounting data are from the Global Trade Analysis Project (GTAP) database version 6.0 benchmarked to 2001. The data include national production and international trade flows.

The import protection data are based on a thorough effort to include use of preferences in a matrix of global import protection data (Bouët and others 2004). These data are the product of a joint effort of the U.N. International Trade Centre, UNCTAD, the WTO, and CEPII. An important contribution of this project has been the exhaustive coverage of preferential trade arrangements across the world and calculations of the ad valorem equivalents of specific duties. Combined with differences in the bilateral composition of trade, the result is that protection varies by sector and partner for each importer. These data have in turn been integrated with the GTAP database for 2001. For this study, the data were further modified to assume full use of the $2001 \mathrm{EU}$ Everything but Arms initiative and the U.S. AGOA for African countries benefiting from more liberal rules of origin, as this has been implemented over a period extending beyond the benchmark year of the original protection data. Elimination of quotas on textiles and clothing trade has also been imposed on the benchmark as

17. See, e.g., IMF (2003), Alexandraki and Lankes (2004), and Brenton and Ikezuki (2005).

18. The 34 regions are the European Union (EU25), Turkey, Russian Federation, Other Europe, Middle East, North Africa, Botswana, Madagascar, Malawi, Mozambique, South Africa and Namibia, Tanzania, Uganda, Zambia, Other Sub-Saharan Africa, Canada, Mexico, United States, Central America, Caribbean Islands, Argentina, Brazil, Other South America, Japan, High-income Asia, China, Vietnam, Other Southeast Asia, Bangladesh, India, Sri Lanka, Other Central and South Asia, Oceania, Australia, and New Zealand. The 24 sectors are rice, wheat, other cereals, horticulture and other crops, sugar, intensive livestock and products, cattle and beef products, milk and dairy, cotton, other agriculture, processed food products, textiles, clothing, leather goods, extraction industries, petroleum and chemicals, ferrous and nonferrous metals, motor vehicles, metal and electro-technical, other industries, construction, trade services, transport services, business services, and other services. 
required by the implementation of the wTO Agreement on Textiles and Clothing as of January $1,2005 .^{19}$

The model is a standard general equilibrium model, with Cobb-Douglas consumer demand over broad product categories and constant elasticity of substitution-based demand within product categories. The overall theoretical structure of the model follows Francois, van Meijl, and van Tongeren (2005). For primary sectors, this is Armington-based trade. Manufacturing and business service sectors are modeled as monopolistically competitive, whereas the extraction and construction sectors are modeled with industrywide scale economies. Scale elasticity estimates are based on Antweiler and Trefler (2002) and Francois (2001). Factor supplies are fixed nationally and are allocated between sectors through factor markets. ${ }^{20}$

The experiment involves elimination, on a multilateral basis, of all OECD import tariffs on all goods. This includes the ad valorem equivalents of specific tariffs and tariff-rate quotas and takes into account the prevailing preference programs as reported by CEPII. A subexperiment was also conducted, with these tariffs eliminated first for the eu alone, to provide an opportunity to identify the full magnitude of preference erosion for a sample of least developed and low-income countries (conceptually represented by area $\mathrm{C}$ in figure 2 ) and to identify the share of the effects that are due to EU preferences. Finally, the estimate of EU preference erosion was recalculated after adjusting for the administrative cost threshold (4 percent for manufactures and 15 percent for agriculture) identified in the previous section. This has a substantial impact on the estimated scope for preference erosion. The recalculation involves two steps. For sectors where the most favored nation tariff is below the threshold, no preference use is modeled, and so there is no erosion. For sectors where use is modeled, recovery of the deadweight costs proxied by the threshold values is allowed for once tariffs are eliminated.

Estimates of the annual dollar impact of full preference erosion on real national income are shown in table 3, which includes the impact on the least developed countries in Sub-Saharan Africa as well as on other low-income countries in the sample (using the World Bank classification of countries by income). The tables reveal that Eu preferences are very important, as a bilateral measure, for Sub-Saharan African countries. Given the current trade policy landscape, and before adjusting for use rates, Eu preferences are estimated to be potentially worth some $\$ 460$ million a year to African least developed countries. Asian countries benefit less, with the exception of Bangladesh (\$100 million). These countries therefore stand to lose-all other things equal-from a move by the Eu to lower most favored nation trade protection.

19. This is of course an important dimension of preference erosion in its own right, insofar as the constraint on the most efficient producers under the Agreement on Textiles and Clothing implied there was an "implicit" preference for the non- or less constrained developing country exporters. The impacts are assessed in greater detail in Francois and Woertz (2006).

20. The full model can be downloaded at http://www.intereconomics.com/francois/data.htm. 


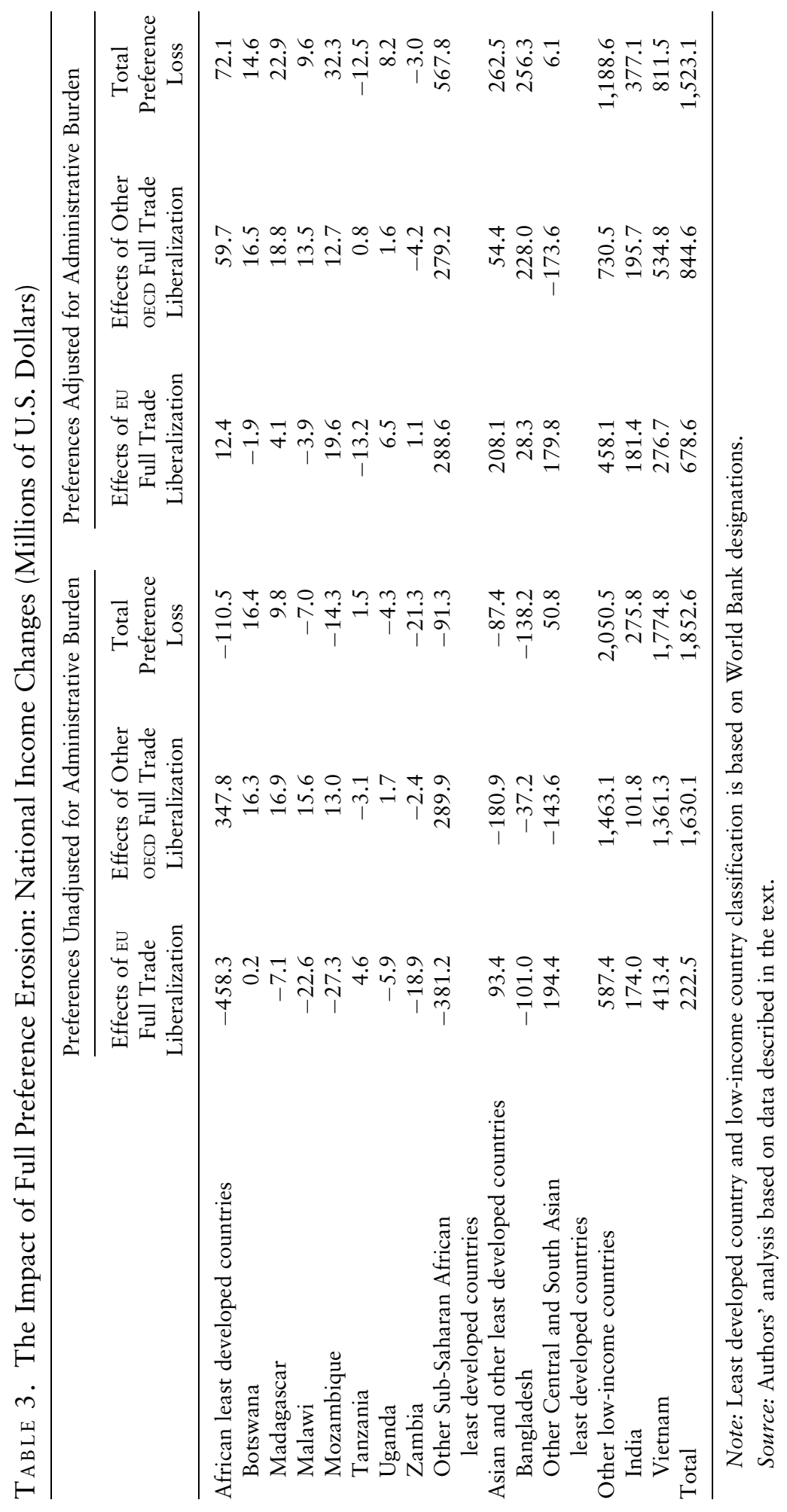


Other developing country groups stand to gain-these are the "less preferred" in the overall hierarchy of preferences. ${ }^{21}$ Indeed, the gains for other low-income countries reveal why developing countries are at odds over preferences in discussions in the WTO. One group gains at the expense of the other. Although the potential preference rents probably do not all accrue to the exporting countries (Olarreaga and Özden 2005; Özden and Sharma 2006), the estimates give a sense of what is at stake. ${ }^{22}$

The welfare estimates here cannot be compared directly with the results from recent partial equilibrium-based analyses of erosion (such as IMF 2003 and Alexandraki and Lankes 2004), which focus on trade effects. The International Monetary Fund (IMF 2003) estimates a potential export revenue loss of some $\$ 530$ million from preference erosion resulting from a 40 percent cut in protection by Canada, the EU, Japan, and the United States. This assumes that preferences are fully used and that developing countries get all the associated rents. Alexandraki and Lankes (2004), focusing only on middle-income countries, conclude that potential erosion impacts are less than 2 percent of total exports for the most preference-dependent countries. Limão and Olarreaga (2006) estimate that income transfers to least developed countries of $\$ 266$ million would be needed to equal the transfers implied by existing preference programs. This is a one-year, short-run effect-all else equal, the net present value is argued to be several times higher. Their results are in line with those reported here, assuming away the compliance costs associated with preference programs (which they do).

If preference erosion is viewed in the broader context of potential tariff reduction by all OECD countries, not just EU members, the magnitude of the total losses is reduced. In part, this is because the Eu has been the most aggressive in using preferences as a tool for development assistance-such programs in other OECD countries have been subject to greater exceptions (for example, the exclusion of apparel from the U.S. Generalized System of Preferences programs and the fact that AGOA does not cover all products). Thus, the gains associated with non-EU most favored nation tariff reductions will partially offset losses due to Eu liberalization. For Sub-Saharan Africa, the overall losses will be reduced significantly. In addition, low-income countries in Asia stand to gain substantially from other OECD tariff reductions. ${ }^{23}$

What are the implications of taking into account the threshold estimates of compliance costs? The right panel of table 3 reports a second set of estimates for preference erosion tied to Eu preferences and all other OECD preferences. The left panel shows that the Eu preferences are the dominant issue at play. The estimates

21. The income effects are mirrored in the trade effects, which reveal that export reductions map to income reductions (not reported). This is fully consistent with the earlier discussion of figure 1.

22. As discussed in Hoekman and Prowse (2005), a case can be made that even if exporters do not get the rents they should get them. In a normative discussion that focuses on offsetting the loss from preference erosion, one can argue that account should be taken of any "missing" rents.

23. As noted by Anderson, Martin, and van der Mensbrugghe (2006), the gains are even greater if developing country reforms are also considered. 
in the right panel are based on the earlier estimate of the compliance costs for EU trade preferences. These costs are eliminated as part of the experiment. Preference use is also removed in the base data when most favored nation rates are below these compliance costs.

The magnitude of preference erosion changes dramatically overall, with the change varying across countries. For Bangladesh, which specializes in high-tariff manufacturing categories such as clothing that are subject to restrictive rules of origin, the income effects of potential erosion change from a loss to a gain. For Madagascar too, potential losses turn into potential gains. The reason for these results is that the compliance costs associated with implementing preference programs bias estimates of the value of preferences upward. Overall, allowing for compliance costs, there are no longer significant losses for African least developed countries as a group, though there are for individual countries. What this says then is that on net, Eu preferences do not really offer collective benefits to African least developed countries. To the extent that individual countries benefit, blocking multilateral reductions to maintain these benefits involves hurting some (neighboring) countries with no real net benefits for the region as a whole. These results also point to the need for country-by-country analysis and assessments of the potential impacts of preference erosion. ${ }^{24}$

The results in table 3 imply that the magnitude of any transfer needed to offset (or compensate for) the effect of erosion is much smaller when all OECD countries liberalize than when the eu alone liberalizes. Individual least developed countries stand to lose from tariff reductions in sectors or products where preferences matter. However, they also stand to benefit from improved overall access to OECD markets, a process that may outweigh any more direct losses on a bilateral basis from erosion of preference margins. They also stand to gain from better access to other developing country markets. While not modeled in this study-as the more advanced developing countries have not granted significant preferential access to low-income countries-other research has shown that much of the potential market access gains for the poorest countries are in other developing countries (Francois, van Meijl, and van Tongeren 2005; Anderson, Martin, and van der Mensbrugghe 2006).

\section{Concluding Remarks}

Because of concern that OECD tariff reductions will translate into worsening export performance for the least developed countries, trade preferences may be a stumbling block to obtaining broad-based support for deep liberalization by OECD

24. IMF (2003) concludes that individual least developed countries may suffer more than average because of the concentration of their exports in products that enjoy deep preferences. Of the least developed countries, Cape Verde, Haiti, Malawi, Mauritania, and São Tomé and Príncipe are the most vulnerable to preference erosion. Alexandraki and Lankes (2004) conclude that six middle-income countries-Belize, Fiji, Guyana, Mauritius, St Kitts and Nevis, and St Lucia-would also be significantly affected, with predicted export declines ranging from 11.5 percent for Mauritius to 7.8 percent for Fiji. 
countries in the WTO. This article examined the potential magnitude of full preference erosion, through an econometric assessment of actual use of preferences and numerical modeling of full elimination of OECD tariffs. Strong statistical evidence was found that administrative burdens lead to underuse of preferences. This presumably reflects rules of origin and related hurdles in the way of actually using trade preferences. These substantially reduce the actual value of preferences.

What are the policy implications of these findings? Preferences can have an impact only if there is a nonzero tariff in the importing market. Two-thirds of the major items Africa exports to Canada, for example, face zero most favored nation tariffs, and 69 percent of eu imports from Africa (by value) in 2000 faced zero most favored nation duties (Stevens and Kennan 2004). One policy option sometimes suggested is to raise trade barriers to increase the value of preferential access. This would clearly be globally welfare reducing, however. More common is the argument that preferred developing countries should not lose any more preferential access to highly distorted OECD markets. The result would be a potential status quo bias, with potentially significant opportunity costs of liberalization forgone. Evidence also suggests that interests in developed countries may be extracting a significant share of the rents from preferential access (Francois and Wooton 2005; Olarreaga and Özden 2005; Özden and Sharma 2006). This points to a political economy of support for preferences that has nothing to do with genuine development objectives.

In U.S. dollar terms, the largest negative impact of erosion follows from EU liberalization. This suggests that the erosion problem is primarily a bilateral concern $^{25}$ and might therefore best be addressed bilaterally through development assistance financing. ${ }^{26}$ This is not to deny that the recent extension of deeper preferences for least developed countries and other Sub-Saharan African countries by other OECD members has created new preference erosion concerns for beneficiary countries. When Canada, for example, granted duty-free access to clothing imports for certain countries in 2003, exports grew threefold from Bangladesh and sevenfold from Cambodia. But access to the other major OECD market-the United States-remains restricted for key items such as apparel. Indeed, the 2005 wTO Ministerial Meeting in Hong Kong illustrated how strong the resistance in the United States is to granting full duty-free access for all

25. The bilateral nature of the erosion problem is clearest in the case of specific products such as sugar and bananas, where a select subset of preferred countries has been granted large rents through quotaguaranteed access to the highly protected Eu market.

26. Options could be to use instruments such as the European Development Fund or a program such as that adopted in the context of reform of the EU Common Agricultural Policy to provide affected producers in ACP countries with income support and adjustment assistance. A small step in this direction was taken in the recent EU reform of its sugar regime, under which ACP producers were allocated $€ 40$ million in income transfers. Considering that compensation payments to EU sugar producers under this reform are some $€ 1.5$ billion, there should be scope to expand the amounts allocated to developing country producers in the context of such adjustment programs. 
products-particularly those that matter most in terms of export potential. ${ }^{27}$ Thus, the conclusion that multilateral liberalization by all OECD countries has the potential to offset the aggregate amount of erosion created by the removal of EU trade barriers appears robust to the recent deepening of preferential access programs in other OECD countries.

Recent research cited above has shown that in practice, rules of origin may be a binding constraint on the ability of poor countries to exploit preferential access opportunities. For example, Brenton and Özden (2005) document the large supply response that followed the relaxation of origin requirements for eligible countries under the U.S. AGOA program. This supply response is not taken fully into account in the simulations here, although the database was updated to reflect the preferential access granted to least developed countries and other Sub-Saharan African countries. The extension of duty-free access programs to more countries and products implies that the erosion problem is growing. Moreover, if the EU were to follow Canada and the United States in relaxing its rules of origin for least developed countries, the supply response could well be substantial, further reducing the incentive of these countries to support most favored nation liberalization. Indeed, the analysis suggests that relaxation of rules of origin and measures to reduce administrative costs would both enhance the benefits of existing duty-free access schemes and increase the costs of erosion. Actions to achieve this are therefore potentially useful as part of an effort to reduce the short-run impacts of tariff liberalization on preference-dependent countries. $^{28}$

Considering the systemic downsides, limited benefits, and historical inability of many poor countries in Africa and elsewhere to use preferences, a decision to shift away from preferential "trade as aid" toward more efficient and effective instruments to support poor countries could both improve development outcomes and help strengthen the multilateral trading system (Hoekman and Prowse 2005; Zedillo and others 2005). More effective integration of the poorest countries into the trading system requires instruments aimed at improving the productivity and competitiveness of firms and farmers in these countries. Supply constraints are the primary factors that have constrained the ability of many African countries to benefit from preferences. This suggests that the main need is to improve trade capacity and facilitate diversification. In part, this can be pursued through a shift to more (and more effective) development assistance

27. The final compromise was to allow 3 percent of all tariff lines-the most politically sensitive items - to be excluded from duty-free access programs for the least developed countries. With exports from most developing countries concentrated in just a few tariff lines, this can imply that the majority of a country's exports could be excluded. For example, more than 70 percent of Bangladesh's exports to the United States are in 70 tariff lines that together account for less than 1 percent of U.S. tariff lines.

28. Annex F of the Hong Kong wTo Ministerial Declaration dealing with Least Developed Countries Agreement-specific proposals specifies that WTO members must ensure that preferential rules of origin applicable to imports from least developed countries are transparent and simple and contribute to facilitating market access. 
that targets domestic supply constraints as well as measures to reduce the costs of entering foreign markets. Actions in these areas would assist firms and communities that stand to lose from preference erosion while benefiting a much larger set of agents by enhancing the gains from trade opportunities.

\section{REFERENCES}

Alexandraki, K., and H. P. Lankes. 2004. "The Impact of Preference Erosion on Middle-Income Countries.” IMF Working Paper 04/169. International Monetary Fund, Washington, D.C.

Anderson, K., W. Martin, and D. van der Mensbrugghe. May 9, 2006. "Doha Merchandise Trade Reform: What's at Stake for Developing Countries?” World Bank Economic Review 20(2), 10.1093/wber/lhj009.

Anson, J., O. Cadot, A. Estevadeordal, J. de Melo, A. Suwa-Eisenmann, and B. Tumurchudur. 2005. "Assessing the Costs of Rules of Origin in North-South PTAS with an Application to NAFTA." Review of International Economics 13(3):501-17.

Antweiler, W., and D. Trefler. 2002. "Increasing Returns and All That: A View from Trade.” American Economic Review 92(1):93-119.

Bouët, A., Y. Decreux, L. Fontagne, S. Jean, and D. Laborde. 2004. “A Consistent, ad-valorem Equivalent Measure of Applied Protection across the World: The MAcMap-HS6 Database.” CEPII Discussion Paper 2004-22. Centre d'Etudes Prospectives et d'Informations Internationales, Paris.

Brenton, P., and M. Manchin. 2003. "Making Eu Trade Agreements Work: The Role of Rules of Origin.” The World Economy 26(5):755-69.

Brenton, P., and T. Ikezuki. 2005. "The Impact of Agricultural Trade Preferences, with Particular Attention to the Least Developed Countries.” In M. Aksoy and J. Beghin, eds., Global Agricultural Trade and Developing Countries. Washington, D.C.: World Bank.

Brenton, P., and C. Özden. 2005. "Trade Preferences for Apparel and the Role of Rules of Origin: The Case of Africa." World Bank, Washington, D.C.

Cadot, O., C. Carrère, J. de Melo, and A. Portugal-Perez. 2005. "Market Access and Welfare Under Free Trade Agreements: Textiles Under NAFTA.” World Bank Economic Review 19(3):379-406.

Cadot, O., A. Estevadeordal, A. Suwa-Eisenmann, and T. Verdier, eds. 2006. The Origin of Goods: Rules of Origin in Preferential Trading. New York: Oxford University Press.

Cadot, O., C. Carrère, J. de Melo, and B. Tumurchudur. Forthcoming. "Product Specific Rules of Origin in Eu and us Preferential Trading Agreements: An Assessment.” World Trade Review.

Candau, F., L. Fontagné, and S. Jean. 2004. "The Utilization Rate of Preferences in the Eu." Centre d'Etudes Prospectives et d'Informations Internationales, Paris.

Carrère, C., and J. de Melo. 2004. "Are Different Rules of Origin Equally Costly? Estimates from NAFTA.” CEPR Discussion Paper 4437. Centre for Economic Policy Research, London.

De Gorter, H., and E. Kliauga. 2006. "Reducing Tariffs versus Expanding Tariff-Rate Quotas." In K. Anderson and W. Martin, eds., Agricultural Trade Reform and the Doha Development Agenda. New York: Palgrave Macmillan and World Bank.

Francois, J. 2001. "The Next wTo Round: North-South Stakes in New Market Access Negotiations." University of Adelaide, Centre for International Economic Studies, Adelaide, Australia, and Tinbergen Institute, Amsterdam and Rotterdam.

Francois, J. F., and I. Wooton. 2001. "Trade and Competition in Shipping Services and the Gats.” Review of International Economics 9(2):249-61.

- 2005. "Market Structure in Services and Market Access in Goods." CEPR Discussion Paper 5135. Centre for Economic Policy Research, London. 
Francois, J., and J. Woertz. 2006. "Rags in the High Rent District: The Evolution of Quota Rents in Textiles and Clothing." Yale University, Yale Center for the Study of Globalization, New Haven, Conn.

Francois, J., H. van Meijl, and F. van Tongeren. 2005. "Trade Liberalization in the Doha Development Round.” Economic Policy 20(42):349-91.

Hansen, B. 2000. "Sample Splitting and Threshold Estimation." Econometrica 68(3):575-603.

Herin, J. 1986. "Rules of Origin and Differences between Tariff Levels in EFTA and in the EC." Occasional Paper 13. European Free Trade Association, Economic Affairs Department, Geneva.

Hoekman, B., and S. Prowse. 2005. "Economic Policy Responses to Preference Erosion: From Trade as Aid to Aid for Trade.” Policy Research Working Paper 3721. World Bank, Washington, D.C.

IMF (International Monetary Fund). 2003. "Financing of Losses from Preference Erosion, Note on Issues Raised by Developing Countries in the Doha Round.” WT/TF/COH/14. Washington, D.C.

Limão, N., and M. Olarreaga. May 17, 2006. "Trade Preferences to Small Countries and the Welfare Costs of Lost Multilateral Liberalization.” World Bank Economic Review 20(2), 10.1093/wber/ lhj013.

Olarreaga, M., and C. Özden. 2005. "AGOA and Apparel: Who Captures the Tariff Rent in the Presence of Preferential Market Access?” World Economy 28(1):63-77.

Özden, C., and G. Sharma. May 4, 2006. "Price Effects of Preferential Market Access: The Caribbean Basin Initiative and the Apparel Sector.” World Bank Economic Review 20(2), 10.1093/wber/lhj008.

Stevens, C., and J. Kennan. 2004. "Making Preferences More Effective.” Briefing Paper. Institute for Development Studies, Sussex.

World Bank. 2005. World Development Indicators Database. Washington, D.C.

Zedillo, E., J. Audley, S. Evenett, J. Francois, E. Fuller, G. Helleiner, B. Hoekman, F. Ismail, H. P. Lankes, R. Melendez-Ortiz, P. Messerlin, D. Njinkeu, H. Pack, S. Page, S. Prowse, J. Roy, K. Saggi, J. M. Salazar, S. Siphana, T. Verdier, and L. A. Winters. 2005. "Strengthening the Global Trade Architecture for Economic Development: An Agenda for Action.” Yale University, Yale Center for the Study of Globalization, New Haven, Conn. 